\title{
The Post is Female
}

\section{by Megan Schillereff, Ball State University}

\begin{abstract}
This paper examines the long-standing post-apocalyptic tradition of male posthuman representation throughout the timeline of the apocalyptic genre, from the time of the medieval knight up to the age of the modern superhero. As this paper argues, the gender dynamics in most posthuman fictions traditionally emphasizes male ability and female inability. Despite this, there is emerging contemporary young adult literature that is giving voice to the self-actualized-instead of the sexually awakened - female posthuman. In doing so, this young adult series explores the importance of representing the genders equally in terms of their ability to prevent apocalypse and fight to save their world.
\end{abstract}

Post-apocalyptic literature has shown time and time again that whenever a cataclysm is on the rise, a hero is never far behind. For most of history-and for most of apocalyptic literature-that hero has been male. However, recent additions to the post-apocalyptic genre have introduced female protagonists who help fight off the end of the world. One example of such an addition is the Shatter Me series by Tahereh Mafi, which features a female posthuman as the apocalypse-preventing hero. I am arguing that the Shatter Me books are important to apocalyptic literature because they take a traditionally male-dominated genre and give readers a strong and capable female posthuman, one who can help prevent apocalypse through her self-actualized powers. By doing this, these books show the up-andcoming generations that both men and women are equally endowed with the ability to right the wrongs in their world and prevent apocalypses.

To fully explain why having a female lead in these books is so important, I will be showing why and how a female protagonist is part of a shifting, posthuman gender dynamic within the apocalyptic genre. I will do this by first looking at the history of the apocalypse through a study of events that helped shape and mold our current definition of apocalypse into what it is today. I will outline the evolving definitions regarding apocalypse from the biblical connotation up through the modern idea of apocalypse.

The biblical idea of apocalypse had a tone of hope; it was to be a moment of reunion with providence. However, as wars and disease ravaged the globe, the meaning of apocalypse shifted until it was just definable as an end of the world. It is important to look at the historical evolution of the definition of apocalypse because of how it relates to gender 
dynamics. In the beginning, the apocalypse was tied to religious ideas, and most religious texts-especially in the Western world-heavily favor males over females as the heroes of their tales. During the various wars men were fighting throughout history, the male dominance of the apocalyptic genre remained. Even as the idea of apocalypse evolved, men continued to be the ones who fought to change their world, while, historically, women were not often granted that same opportunity.

One source that reflects this example of a male-centered tradition of war and apocalypse is the Book of Revelation. Revelation is one of the oldest, and most canonized, examples of apocalypse that we have in the Western world. It is also a text full of gender dichotomies and violence. By looking at the far-reaching implications that these aspects of Revelation have had on contemporary society, the current impacts on our gendered worldview become exceedingly clear. If one of the most formative apocalyptic narratives of our time features only male protagonists as being capable of saving the world, is it a surprise that our contemporary literature still doesn't give true credence to capable female posthumans?

Secondly, I will examine the gendering of posthumans throughout history by looking at chronological examples of posthumans, dating from medieval times to the age of the superhero and up into contemporary literature. As defined by Mads Rosendahl Thomsen in his essay, "Posthuman Scale," a posthuman "constitute[s] a species developed from humanity" (32). A posthuman is a form of humanity that has been forced, most commonly by a cataclysmic event, to evolve beyond the limitations of their previous humanness. The existence of a posthuman is apocalyptic in nature because posthumans are a side effect of the apocalypse. The humans that survive the apocalyptic event become posthuman because they have adapted enough by evolving from their original form of humanity. As such, examining posthuman representation within the apocalyptic cannon is crucial because it shows the type of people society sees as capable and empowered.

Knights in shining armor (a male occupation) are one of the first functioning examples of a posthuman. They helped to protect their countries and kings from a myriad of apocalypse-like scenarios, both offensively and defensively. After the knights, the timeline then progresses into the representation and implementation of superheroes, also a traditionally male genre. Superheroes are probably one of the best examples of the posthuman in our media today, as they all are humans gifted with abilities that render them capable of saving their world.

The purpose behind discussing these points on the posthuman timeline is to 
establish both chronological and historical examples of male representation as posthuman characters and to show that, while males have been presented as capable of preventing the apocalypse for centuries, it's only recently that female posthumans have entered the equation. Contemporary female posthuman representation within apocalyptic literature today is a bit of a gray area. Even though writers are employing females, they often only operate in roles of sex appeal, or they are reliant on a form of sexual awakening to become empowered. Both these scenarios are problematic applications of the female posthuman because showing female characters in this way creates a precedent where females can only function in an apocalyptic environment as a sexual body, not as a self-actualized, autonomous one.

This current view of the posthuman is why I will be taking a closer look at the importance of Shatter Me's use of Juliette, a female posthuman. Juliette is a protagonist who achieves her true power and potential not through sexual awakening but rather through a moment of self-actualization, brought on by her grasping the true extent of her autonomy. While looking at Shatter Me, I will be addressing why Juliette is a crucial addendum to the post-apocalyptic tradition. She is a strong female character capable of changing her world, and she does it not by employing her sexuality but rather through a realization of self.

\section{HISTORY OF THE APOCALYPSE}

In order to discuss the gendered representation of the posthuman throughout history, I first need to explain some of the background of the apocalyptic genre. To grasp some of the history that has impacted our societal viewpoint of apocalypse, it is paramount to understand where these views originated and to look at the moment in time in which the apocalypse (in the current and modern understanding of the word) began to appear within literature. In her article "Apocalypse Not Quite: Romanticism and the Post-Human World," Olivia Murphey looks at the cultural moments that brought us to our current understanding about apocalypse. She opens her paper stating that "[t]he word apocalypse seems largely to have shrugged off its ancient meaning of 'revelation' and now stands in for any end-of-theworld scenario; the Oxford English Dictionary has, as its most recent definition, 'a disaster resulting in drastic, irreversible damage to human society or the environment, esp[ecially] on a global scale" (245). As Murphey states, this current definition is not the only version of apocalypse to have ever existed; it is merely the most recent version of apocalypse to which our society subscribes.

The current definition comes from a few different moments in history. For example, 
Murphey cites the Book of Revelation as having a cultural impact on the definition of apocalypse, as it is one of the most influential apocalyptic texts in the Western world. Additionally, the Book of Revelation has had undeniable influence on the gender roles of apocalypse, as it was one of the first canonized apocalyptic texts, and it features males as being the ones capable of impacting the apocalypse. Murphey then goes on to explain that it was around 1790, with "the unprecedented upheaval of the French Revolution," that many mindsets shifted to the idea of "apocalyptic destruction" instead of the godly revelation they had all been previously hoping for (245). Generations of wars ravaged countries, plagues destroyed cities, and disasters kept happening, all leading up to the "gaining traction [of] the Nuclear Age" (Murphey 245). This combination of events had lasting impacts on how we currently view apocalypse. The seeds of the modern mentality regarding apocalypse were sown in the late eighteenth century, and the idea of the apocalypse as the disastrous end of the world became firmly cemented within the minds and fears of the general population with the onset of the nineteenth century. As Murphey explains, it was "after 1815, that our contemporary, negative definition of apocalypse was first theorized" (246). Yet, even as the definition of apocalypse shifted away from biblical connotation, the masculine tradition laid out in the Book of Revelation remained. Men continued to be the bodies able to fight for the change they wanted to see in their worlds, whereas women rarely had the same abilities.

The Book of Revelation is responsible for some of the most far-reaching impacts within the apocalyptic genre, especially in regards to society's inherent gendering of who is perceived as capable of preventing apocalypse. Mary Wilson Carpenter introduces this argument in her article, "Representing Apocalypse: Sexual Politics and the Violence of Revelation," saying, "I will argue that Revelation's violence is a representation of a continuing power dynamic of gender and sexuality in Western culture" (110). Carpenter's main question throughout the piece is "[w] hat were the effects of power generated by what was said [in Revelation]?” (110). I think the answer to Carpenter's question can be clearly seen in the narratives about posthumans and apocalypse that we have been telling each other throughout time.

This is a key point of my argument, that the stories we've been telling ourselves for millennia all look eerily similar in regard to their long-standing male traditions, whether it be a knight in shining armor, a superhero, or-in the case of Revelation- angels. All these heroes share two common traits: their masculinity and their ability to save the world. Given the social impact that Revelation has had on our world, it's not surprising that Carpenter questioned whether a female apocalypse was a "textual/ sexual impossibility given ... the 
culture" (111). The influence that the Book of Revelation has had on apocalyptic gender roles cannot be overlooked; this discourse has shown that the gender politics coined in Revelation have been carried-out through our society. Evidence of this can be seen both in the way we talk about the apocalypse and the way we talk about who has the power to prevent it.

\section{THE TIMELINE OF THE POSTHUMAN}

Now that I have shown some of the formative impacts within the apocalyptic genre, I can begin to discuss the character who is often endowed with the ability to save the world from apocalypse, the posthuman savior. To reach the ultimate goal of discussing why Juliette is so impressive as a female posthuman protagonist, I am first going to outline the gender timeline of the posthuman character within post-apocalyptic literature so that the masculine history of the genre is visible. To fully grasp the relevance of the posthuman, we must first understand what a posthuman is.

To restate the explanation offered in the beginning of the paper, a posthuman is any human who has progressed and evolved in their humanity to a point where they are no longer like the original form of humanity. Mads Rosendahl Thomsen explains in his essay on posthuman scale that "[a] very simple classification would be that posthumans constitute a species developed from humanity" (32). While he lists several different classifications that could be used to identify a posthuman, such as lifespan or size, he notes that the basic identification of a posthuman will be their normalcy-or lack thereof. As he explains, "humans have a strong sense of normality ... it is clear that ... what is normal and what is not... [will] determine whether a new era has arrived that can no longer be called human but should be called posthuman instead" (32). With that working definition of posthumanism, we can begin to look at one of the earliest examples of operating posthuman bodies: medieval knights in armor.

Raymund Papica introduces this example of one of the first posthumans in his article, "The Armor Network: Medieval Prostheses and Degenerative Posthuman Bodies." In this work, Papica presents "the armored knight, as a representation of the hyper masculine chivalric ideal" (1). Papica sets up the connection between the inherent masculinity of the posthuman as he goes on to explain the link between knights and posthumans, stating that "the concept of the posthuman ... finds its beginnings in the premodern period, and specifically, in the nexus of knight and armor" (2). The concept of knights as some of the first posthumans can be easily seen by looking back to Thomsen's definition of the posthuman: a human who exists outside the realm of the human "normal." Knights were far 
from normal in comparison to most of the plebeian humanity of the medieval era. They were supposed to be morally, and physically, superior to their fellow man.

Their elevated morality can be seen in the code of chivalry that they were expected to uphold, a code that operated outside the norm, as it wasn't a lifestyle ascribed to by the majority of the population; and their physical superiority can be seen by their use of armor. Papica's support for the idea that knights are posthumans consists of the fact that they use metal armor to improve their humanity. They are one of the first examples of humans using technology to upgrade their bodies. As he explains, "the trope of armor [can] trace and unravel the intersecting relationships between the ... posthuman body ... [By] reading armor ... [as a] posthuman body" (9). By wearing armor to enhance and improve their bodies - and by extension, their humanity — knights became some of the first posthumans. Knights used their armor to advance themselves above and beyond the "normal" realms of their fellow humans and, in doing so, cemented their place as one of the first examples of posthumans operating within our world.

The idea of knights in shining armor as the first posthumans helps to make clear the connection to the male tradition of the posthuman. However, the reign of the knight didn't come to an end in the medieval ages; rather it has been carried into the twentieth and twenty-first centuries - in the form of a cyborg. Just as a knight was one of the first posthumans, it is also one of the earliest versions of a cyborg. As Steve Dixon, a professor at University of Salford, UK, explains "cyborgian performances include human bodies and metal prostheses" (Papica 4). So, arguably, where there is a human body using metal or technology as an enhancement, there is a type of cyborg.

Today, cyborgs are most commonly seen in superhero culture. In a similar way to how cyborgs are comparable to the modern version of knights in shining armor, superheroes are one of the best versions of posthumans that can be seen in our world today, metahumans who have progressed beyond the previous bounds of humanity to become something more: normally they complete this evolution as an answer to a cultural need of that era. Scott Jeffery addresses this connection between the posthuman and the superhuman in his book, The Posthuman Body in Superhero Comics: Human, Superhuman, Transhuman, Post/Human. Within this book, Jeffery gives his own working definition of a posthuman, saying that a posthuman "would almost certainly hinge upon just such a blurring of categorical boundaries, whether between the natural and the artificial, [or] the human and the machine" (11). This definition still works with Thomsen's idea of "normalcy:" a superhuman-by the very aspect of existing - is outside the realm of normalcy because of 
their incredible physical abilities.

The blurring of boundaries and the existence outside the norm work hand-in-hand to show a more comprehensive picture of superheroes fitting as posthumans. Superheroes represent an important segment on the posthuman timeline because they serve as the answer to a societal need. In the same way that a posthuman protagonist is called into existence to prevent the apocalypse, the superhero is called into existence to help save their respective world or city from cataclysm, while at the same time they help to create "new conceptual spaces and metaphors adequate to our current ... society" (Jeffery 12). In this way, they answer a cultural need by being an outlet for the expression of current societal emotions. This is identical to the function of a posthuman protagonist within apocalyptic literature, where the protagonist arises to help prevent the apocalypse. With the understanding that posthumans serve to answer a societal call, the danger of contemporary culture only acknowledging male bodies as capable of helping becomes ever clearer. If men are repeatedly represented as the majority of superheroes and posthumans, then we are reinforcing the mentality laid in Revelation that men are the only ones qualified to prevent apocalypse.

The male superhero body and the male posthuman body exist and operate in very similar ways; as such, it comes as no surprise that Jeffery also presents superheroes as a way to read the timeline of posthumans by following the male tradition, saying, "[I]n many respects this is what the history of the comic book posthuman offers; an unbroken chain of posthuman representations put to very different uses and given different meanings at certain times" (17). And, remaining true to the connection between posthumans and superheroes, Jeffery nods his hat to the male tradition within the superhero field, saying that "the comic book posthuman body still regularly manifests itself as a white, male, muscular body" (17). Just as the posthuman protagonist within apocalyptic literature is populated by a male majority, so too is the superhero field.

And while there have always been some female superheroes, it is only in recent years that they have evolved past the point of only existing as plot points in their male counterparts' storylines. The same can be said of the female posthuman. It is only within recent years that post-apocalyptic literature has moved into a place where it has begun to incorporate female protagonists. However, this improvement doesn't mean that they have been implemented flawlessly into the apocalyptic field. There are still some issues with the representation of the female posthumans, as the gendered view of apocalypse, dating all the way back to Revelation, continues to have impacts on the genre. In "Docile Bodies, 
Dangerous Bodies: Sexual Awakening and Social Resistance in Young Adult Dystopian Novels," Sara K. Day explores some of these contemporary issues surrounding female protagonists within apocalyptic stories, including the "problematic treatment of adolescent's women's sexual awakening as impetus for social resistance in dystopian novels for young adults" (76). It is a common occurrence within apocalyptic literature to feature a female protagonist, give her a love interest, and have her moment of empowerment be focused around her sexual awakening or around her sexual acceptance of said male love interest. Day is able to list several young adult novels that involve such a plot, including “Scott Westerfelds's Uglies, Julianna Baggott's Pure ... Veronica Roth's Divergent," and she even notes it as a force at work in Suzanne Collins' Hunger Games (76). I would like to take a small step back to clarify that I am not here to argue that women shouldn't be allowed sexual autonomy. However, I am arguing that sexual awakening shouldn't repeatedly be sourced as the catalyst for a female character discovering her strength.

An awakening - of any kind - can be a very empowering moment. Restricting the moment of that awakening to a sexual encounter shows the gender corruption embedded within the apocalyptic genre. Day explains that "[b]y removing adolescent women to potential dystopian futures, authors complicate the question of sexual awakening as empowerment, as their novels both reflect contemporary Western culture and anticipate futures in which young women's bodies continue to be treated as contested and contestable spaces" (79). By setting up female protagonists to receive their moment of empowerment through a sexual awakening, apocalyptic stories simultaneously create an environment where a female's bodily autonomy is presented as possible, while - in the same breathreminding women that their bodies are objects and spaces that can be up for debate and possession.

This problematic mentality is a situation that still permeates our contemporary representations of gender: if a female protagonist is only able to become fully actualized as a posthuman through a sexual awakening of some sort, then her powers don't truly come from her own body but rather from the undercurrent of male necessity. As there is also a very limited amount of homosexual representation within the apocalyptic field, a female character is almost always reliant on a male counterpart to achieve her true potential as a posthuman. It's easy to see how this is a problematic way of presenting female posthumans within the apocalyptic genre, as it creates a societal norm for women needing men to become empowered instead of creating a narrative where it is a norm for a female to become empowered through self-actualization. 


\section{SHATTER ME}

By understanding the long male tradition of the posthuman, as well by looking at some of the problematic representations of female posthumans, we have arrived at the novels I am examining: Shatter Me and Ignite Me, by Taherah Mafi. Some may try to argue that my use of these books is hypocritical, as they feature a rather complex love story, but I am not focusing on Juliette's love interests. I am instead focusing on her moments of empowerment as a fully realized posthuman, moments that came separate from a sexual awakening. As I begin to discuss why Juliette is a such an important example of posthuman female representation, I am going to outline the plot of these books so the implementation and execution of Juliette as a posthuman character becomes visible.

As the book opens, we meet our protagonist, Juliette, who is locked away in an underground prison. She is being entrapped there by the dictatorial government power known as The Reestablishment, which has taken over her world. After explaining what her post-apocalyptic world looks like, Juliette begins to delve deeper into her particular form of posthumanism-her lethal touch. She explains,

I don't know when it started. I don't know why it started. I don't know anything about anything except for the screaming. My mother screaming when she realized she could no longer touch me. My father screaming when he realized what I'd done to my mother. My parents screaming when they'd lock me in my room and tell me I should be grateful ... for their humane treatment of this thing that could not possibly be their daughter. (Mafi 25)

Her posthuman abilities seemingly came from nowhere. They were unprecedented and unforeseen, her powers simply manifesting as a symptom of the growing apocalyptic conditions within her world. Because of her powers, her parents saw her as a monster and grew to hate her.

Her parent's disdain of her grew along with their fear of her abilities. It's like Thomsen said: the posthuman exists outside the realm of the normal. Their daughter was no longer a normal human, so their fear turned into hate. They began to tell her that she "ruined their lives ... stole their happiness ... ruined everything" (Mafi 26). And then, the final straw that broke the camel's back: Juliette accidently killed a young boy. She had been in a supermarket, where a young mother had her son on a leash. The child kept pulling at the leash and ended up falling and hurting himself. Juliette, feeling for this boy who was being neglected by his mother, went to pick him up, saying as she remembers the incident, "I thought my hands were helping” (Mafi 130). But instead, her touch killed him. After that, 
her parents handed her over to The Reestablishment, which, after running her through multiple asylums and testing facilities, placed her in the prison. And while trapped there, Juliette's self-loathing and fear of herself continued to fester and grow.

Juliette's power is consistently presented back to her in such a negative light throughout the course of the book that there is almost no way for her to see her powers as anything but a curse. While she may not have started out seeing herself as a monster, it was said to her enough that she eventually began to believe it. And after killing a small boy-even accidently-it is easy to see how she came to feel this way about her abilities. Her revulsion at her powers is part of the reason that it is so important for her awakening to be one of self-actualization instead of one that is derived from her sexuality. Juliette hates and fears her own self for so long: what better way for her to become truly empowered than to accept and find power within herself? Her perception of herself and her powers is what keeps her functioning at a lesser capacity; while she is subjected to the opinions and voices of outside forces, her true problems with her powers come from her own view of them, which is why her moment of empowerment needs to also come from within, not without.

Moving away from Juliette's internal struggle and circling back to the main plot line of the story, Juliette is given a cellmate - an old friend from her childhood, Adam. And then, a short while later, The Reestablishment comes, breaks her cell door down, and drags Juliette out of the prison to the main compound of Sector 45, which functions as the capital of The Reestablishment. Once in the capital, it is revealed that Adam is actually a soldier of The Reestablishment, and he was sent to her as a guinea pig to see whether or not she was insane. Juliette's mental status was a bit of a question mark; since she had lethal touch and had been locked away for years, they feared she might not be fit to be around other humans.

And so, when she didn't kill Adam, The Reestablishment ruled that she was stable enough to take in for experimentation. While in the compound, she meets the leader of Sector 45, Warner. Warner tells her his reasoning for dragging her out of the prison and bringing her to the surface. He wants her to be a weapon. He wants to use her to torture information out of people, saying, "Inflicting pain ... is an incredibly efficient method of getting information out of anyone. And with you? ... well it's cheap. Fast. Effective" (Mafi 134). Juliette rejects Warner, exclaiming, "You think that because I can inflict pain, that I should? ... You think I'm a monster ... I value human life a lot more than you do, Warner" (Mafi 136). 
This facet of Juliette's character is also important to her impending self-actualization. She doesn't want to be a monster, she doesn't want to be used, and she doesn't want to be what other people want her to be. She wants to be her own person, not the monster her parents-or society-see her as and not the monster that she has grown to see within herself. Her desire to be more than the role that society has cast her in shows one of the defining moments that will carry her toward becoming a self-actualized posthuman.

This mentality didn't really work with Warner's plans, however, so he proceeds to manipulate her into several situations where she is forced to use her powers. The most drastic of these situations is when he brings her into a room where metal spikes pierce the floor, ceiling, and side walls every few seconds, and then he sends in a waddling toddler, wearing only a diaper. He watches from behind a concrete wall, lined with two-way glass, as Juliette becomes panicked that the baby could be impaled. Torn between the fear of touching him and the fear of him being injured or killed by a spike, Juliette finally scoops him off the floor and runs to perch on a safe spot of ground. The position Warner has placed her in begins to enrage her, as she just wants to be able to help this child, and yet she knows "it will never be possible" (Mafi 169). She becomes furious: "And suddenly the world shifts out of focus ... I'm overcome by rage ... I don't even understand how my feet move in the next instant. I don't understand my hands and what they're doing or how they decided to fly forward ... I only know ... I want [Warner] to experience the same terror he just inflicted ... I catapult through the concrete walls" (Mafi 169-170). In this moment, Juliette takes her first step in progressing beyond her old capabilities. And she does it through no sexual channels but all through the desire to not be the monster Warner was trying to force her to be.

She reacts in a way that Warner doesn't anticipate: instead of panicking and shutting down, or letting the child die, she bursts through a concrete wall, grabs Warner, and forces him to end his sick test. In doing so, she not only exercises her own autonomous will over her body, but she also discovers a new facet of her powers: super strength. Seeing the small boy in danger reminds her of the boy she killed in the supermarket, and through her desire to not be like her past self, she is able to evolve to a new level in her posthuman powers. This is a part of her self-actualization; she doesn't tap into her superpowers via a sexual awakening, but rather via a moment of strength in which she realizes she doesn't want to be the monster people see her as.

With mounting pressure from Warner, Juliette decides she has to escape from The compound. Adam reenters the story here, apologizing to Juliette and promising he never 
wanted to hurt her. Adam explains that he actually was a double agent, joining The Reestablishment. Together, they manage to make it to a hideout that Adam has been maintaining for years, where he helps keep his younger brother safe. The two are able to stay hidden for a short time before The Reestablishment comes knocking, and they have to flee again, taking Adam's little brother and another double agent with them.

The quartet makes it to an underground resistance cell known as Omega Point. It is revealed that the other double agent, Kenji, is a high-ranking member of Omega Point, and he was sent to work in Sector 45 as a spy on Warner. It is also revealed that Kenji is a posthuman, like Juliette, and that he has the power to turn himself invisible. Upon meeting with Castle, the leader of Omega Point, it is revealed to Juliette that about half of the residents of Omega Point "have some kind of gift" (Mafi 309), including Castle himself, who is capable of an "impossibly advanced level of psychokinesis" (Mafi 311). It is among the people of Omega Point that Juliette first begins to accept her powers as a gift and not a curse.

She is surrounded by other people like herself, and Castle tells her, "[Y]ou are not alone" (Mafi 309). For the first time in her life, she is not a monster or a killer: she is a posthuman surrounded by other posthumans. It is around this time that Castle reveals the purpose of Omega Point. Omega Point serves as the gathering place for some of the last people free of The Reestablishment's control, people who plan to fight back against The Reestablishment and regain power and a voice in their own world. Castle calls Omega Point "the only hope [their] civilization has left," showing how this underground community of rebels is lining up to be the new civilization of the post-apocalyptic world (Mafi 306).

Between the realization that she is not alone as a posthuman and the realization that standing against The Reestablishment is possible, Juliette decides to join Omega Point in their battle against The Reestablishment. She wants to fight to help right the wrongs in her world and to help prevent the apocalypse that The Reestablishment is bringing down on their heads. Through Castle, it is revealed that their world isn't as bad off as it looks. The Reestablishment is the true cause of many of the issues, hiding livestock and growing crops in secret, which they then refuse to share with the starving population. Castle confirms that the damage to the environment is "probably [their] only real problem" (Mafi 307). But everything else can be fixed with the overthrow of The Reestablishment. All this information just cements Juliette's decision to fight alongside Omega Point, and so she begins training.

It is through this training that she begins to unlock more and more facets of her 
power. She learns that her lethal touch is really a highly concentrated field of energy around her skin and that when she projects that power outward, it can shape itself in the form of super strength, granting her the power to hurl rocks or to create earthquake-force tremors. It can even manifest as a bulletproof shield around her body. All of these powers are uncovered not through a sexual awakening but rather through her own desire to improve her body and grow stronger so that she can be a reckonable force in righting the wrongs of her world.

Additionally, in tandem with the growing range of her abilities, her acceptance of herself also grows. She begins to see her powers not as a monstrosity but as a strength. This metamorphosis of thought is captured perfectly on the back cover of the Shatter Me book, as it highlights contrasting thoughts that Juliette has along the course of the book: "I have a curse" becomes "I have a gift" (Mafi). "I am a monster" switches to "I'm more than human" (Mafi). The back of the book also says, "My touch is lethal/ My touch is power ... I am their weapon/ I will fight back" (Mafi). These juxtaposed thoughts show the evolution of Juliette's view about herself as she becomes actualized with her powers. Her mental image of herself switches from seeing herself as a monster to being more than human-a posthuman. This realization is directly linked to the empowerment she achieves through the actualization about the extent of her powers.

Here, we can circle back around to discussing Juliette's place at the end of the posthuman timeline. We have reached a literary moment where a female posthuman character is in the process of achieving the full potential of her power not through a sexual awakening, but rather through a self-actualization of her own powers as an independent entity. As she discovers the true depths of her powers throughout the course of the books, she realizes that her touch's power to suck away someone's life force is no longer her only ability. She learns how to manifest her powers into super-strength and the ability to shield herself-and even others-from harm.

However, the true moment of her empowerment comes slightly later, in the book Ignite Me. This moment comes not when she realizes the depth of her abilities but rather when she realizes that she can turn her lethal touch off and on. Before, she only has the option of living in fear of human contact. Her interactions are regulated to posthumans who have the ability to mute or disable her power, or she has to wear a specialized suit that covers her from head to toe, for other people's safety. She has always "assumed [she is] fated to this life, to an existence in which [her] hands-[her] skin -[will] always, always keep [her] from others" (Mafi 312). Her realization that she could turn her power off and on opens her 
eyes to the fact that she is now fully realized as a posthuman. Her powers can no longer limit or constrict her life. She has the ability to control her powers, and with that ability she can never again be forced into a life she doesn't want. She exalts her discovery, saying, "I can do anything I want now. Be . . . anyone I want. And it'll be my choice” (Mafi 313). This moment is when she becomes truly self-actualized and secure as a posthuman. She isn't reliant on any outside force to empower her: she is completely self-fulfilling.

With this discovery fueling her on, she leads the attack against The Reestablishment and wins, not through the power of love or through a sexual awakening, but through the realization that she is in control of her own body and that she can live the life she wants to. Her powers cannot limit her autonomy as she is now in full control of her incredible physical abilities. She has become a fully realized posthuman.

In conclusion, after examining the long-standing masculine tradition within postapocalyptic literature, the true value of the Shatter Me books can be seen. These books present a posthuman female capable of preventing apocalypse through becoming self-actualized, not sexually awakened. So, circling back to Mary Wilson Carpenter's question: is a female apocalypse a textual or sexual impossibility? I think it safe to say that, while there is a lengthy historical timeline saying it is improbable, it is no longer impossible. Women, both as protagonists and as people, gain more voice and representation every day.

Shatter Me's Juliette is by no means the only female, or the last female, to grace the pages of post-apocalyptic literature. Female representation on the apocalyptic timeline is increasing. A prime example of this shifting dynamic can be seen in young adult literaturelike the Shatter Me series-which continues to employ female posthumans in their texts. These applications may not be without flaws, however, as some of these female posthumans continue to be represented problematically. In addition to that, many scholars worry that the apocalyptic genre is inherently structured to subjugate females. However, while that has been true for the majority of the apocalyptic tradition, characters like Juliette show that for every female protagonist who achieves empowerment through her own autonomy, we as a culture are able to take one step closer to a post-apocalyptic world where both males and females can see themselves being equally endowed with the power to change the world and prevent apocalypse. 


\section{WORKS CITED}

Carpenter, Mary Wilson. "Representing Apocalypse: Sexual Politics and the Violence of

Revelation.” Postmodern Apocalypse: Theory and Cultural Practice at the End, edited by Richard Dellamora, University of Pennsylvania Press, 1995, pp. 105-115.

Day, Sara K. "Docile Bodies, Dangerous Bodies: Sexual Awakening and Social Resistance in Young Adult Dystopian Novels.” Female Rebellion in Young Adult Dystopian Fiction, edited by Sara K. Day, Miranda A. Green-Barteet, and Amy L. Montz, Routledge, Taylor \& Francis Group, 2016, pp. 75-92.

Jeffery, Scott. The Posthuman Body in Superhero Comics: Human, Superhuman,

Transhuman, Post/Human. Palgrave Macmillan, 2016.

Mafi, Tahereh. Ignite Me. Harper, 2014.

Mafi, Tahereh. Shatter Me. HarperTeen, 2011.

Murphy, Olivia. “Apocalypse Not Quite: Romanticism and the Post-Human World.”

Romantic Sustainability: Endurance and the Natural World, 1780-1830, edited by Ben

P. Robertson, Lexington, 2016, pp. 245-259.

Papica, Raymund. "The Armor Network: Medieval Prostheses and Degenerative Posthuman Bodies.” Dissertation Abstracts International, vol. 78, no. 1, July 2017, pp. 1-10.

Rabkin, Eric S. "The Remaking of Zero: Beginning at the End.” The End of the World, edited by Eric S. Rabkin, Martin H. Greenburg, and Joseph D. Olander, Southern Illinois University Press, 1983, pp 1-19.

Thomsen, Mads Rosendahl. "Posthuman Scale.” CounterText, vol. 2, no. 1, 2016, pp. 31-43. 